\title{
Rocky Mountain Snowpack Chemistry Network: History, Methods, and the Importance of Monitoring Mountain Ecosystems
}

\author{
By George P. Ingersoll, John T. Turk, M. Alisa Mast, David W. Clow, Donald H. Campbell, and \\ Zelda C. Bailey
}

\section{Abstract}

Because regional-scale atmospheric deposition data in the Rocky Mountains are sparse, a program was designed by the U.S. Geological Survey to more thoroughly determine the quality of precipitation and to identify sources of atmospherically deposited pollution in a network of high-elevation sites. Depth-integrated samples of seasonal snowpacks at 52 sampling sites, in a network from New Mexico to Montana, were collected and analyzed each year since 1993.

The results of the first 5 years (1993ñ 97) of the program are discussed in this report. Spatial patterns in regional data have emerged from the geographically distributed chemical concentrations of ammonium, nitrate, and sulfate that clearly indicate that concentrations of these acid precursors in less developed areas of the region are lower than concentrations in the heavily developed areas. Snowpacks in northern Colorado that lie adjacent to both the highly developed Denver metropolitan area to the east and coal-fired powerplants to the west had the highest overall concentrations of nitrate and sulfate in the network. Ammonium concentrations were highest in northwestern Wyoming and southern Montana.

\section{BACKGROUND AND PROGRAM HISTORY}

The Rocky Mountain region contains an expansive system of National Parks, National Forests, and wilderness areas, but the region is surrounded by mostly arid lands. In recent years, population growth, water use, and energy development have increasingly affected the resources of natural settings in the Rocky Mountains. Protection of the quality of limited water resources in this region is critical to the preservation of natural mountain ecosystems.

Identifying changes in water quality and processes leading to degradation of water quality is important because alpine and subalpine environments in the region are sensitive to changes in chemical composition of the water. Soils and water typically have limited capacity to neutralize or buffer acidity that may result from airborne contaminants such as nitrogen and sulfur. Atmospheric input of these and other chemicals to these sensitive mountain ecosystems is likely because of fossil-fuel combustion in the region and may harm plant and wildlife populations (Corn and others, 1989). Precipitation that transports contaminants from the air can affect the chemistry of mountain watersheds and alter the chemical balance of these ecosystems (Cogbill and Likens, 1974).

Although several watershed-scale studies have addressed the problem of anthropogenic chemical deposition in small headwater basins in the Rocky Mountains (Turk and Campbell, 1987; Caine and Thurman, 1990; Baron, 1992; Reuss and others, 1993; Campbell and others, 1995; Williams and others, 1996), regional-scale atmospheric deposition data are sparse. In the past, data from National Atmospheric Deposition Program (NADP) (2001) sites provided the only regional estimates of atmospheric deposition (Nilles, 2000). The NADP network is extensive nationwide, but coverage for high-elevation areas [greater than 2,000 meters (m)] in the Rocky Mountains is limited. Although 10-high elevation NADP sites monitor wet atmospheric deposition in Colorado, few sites are operated at higher elevations in Montana, 
Wyoming, and New Mexico, where snowpacks persist with negligible melt through the snowfall season. Thus, a program designed to more thoroughly determine the quality of precipitation and identify sources of atmospherically deposited pollution in the Rocky Mountains was created.

Snowfall provides about 50 to 70 percent of the annual precipitation in headwater basins of the Rocky Mountains from early October to late March (Western Regional Climate Center, 2001). Snowpacks that accumulate during the winter and spring contain an integrated record of chemicals deposited from the atmosphere during these seasons. Because snowmelt supplies most of the freshwater in mountain lakes, streams, and wetlands, monitoring snowpack water quality is important to long-term health of these systems.

In the mid-1980's, U.S. Geological Survey (USGS) scientists began monitoring the response to atmospheric inputs in the chemistry of mountain snowpacks and lakes in western Colorado (Turk and Campbell, 1987; Campbell and others, 1991; Turk and others, 1992). Initially, little was known about the chemical composition of precipitation at high elevations throughout the Rocky Mountain region, and new methods to define snowpack quality were needed because no consistent program of sampling snow in remote wilderness areas existed for large areas such as the Rocky Mountains. The network of sampling sites has grown from a few Colorado sites in the 1980's to more than 52 sites starting in 1993 and extending about 1,500 kilometers $(\mathrm{km})$ from northern New Mexico to northern Montana. The USGS, in cooperation with the National Park Service, U.S. Department of Agriculture (USDA) Forest Service, and other agencies, established this cost-effective and flexible network of sampling sites throughout the Rocky Mountain region to study atmospheric deposition of pollutants over this large area. Requiring only one annual visit, each of the 52 snowpack-sampling sites has been sampled repeatedly each year from 1993 to the present to develop a long-term program for monitoring the most extensive seasonal-snowpack-chemistry network in the world (Turk and others, 2001). The results of the first 5 years of the program are discussed in this report.

\section{SAMPLING METHODS}

The validity of a regional assessment of snowpack chemistry rests on the collection of representative snow samples integrating atmospheric deposition for several months during the snowfall season. Since 1993 the USGS has applied consistent methods for sampling physical and chemical characteristics of regional snowpacks and for detecting chemicals deposited from the atmosphere and accumulated in annual snowpacks throughout the network. The program methods were designed to take advantage of collection of a variety of chemical constituents in a single, composite sample that is representative of the quality of air masses present during most snowfall events contributing to the annual snowpack. Sampling the majority of annual precipitation in just one sample per site also provides an economical advantage so that resources may be directed to many sampling sites, which form a large network. Observation of concentrations of several chemical constituents at several sampling points across a large region indicates distinctive geographic patterns. Consistent multiyear patterns of correlated chemicals such as nitrate and sulfate support the identification of source areas of airborne contaminants.

In addition to sampling for concentrations of major ions such as ammonium, nitrate, and sulfate, techniques were developed to analyze snow samples for stable isotopes of sulfur (Turk and others, 1993; Mast and others, 2001), nitrogen, and oxygen (Kendall and others, 1995; Campbell and others, in press). Because many pollution sources have distinct isotopic signatures, determination of snowpack isotopic composition may provide another means of estimating sources of atmospheric deposition.

Collection of snowpack samples and field data throughout a large network of sites in the Rocky Mountain region during a brief period of weeks before snowmelt requires substantial logistical planning. The success of the snowpack-chemistry network depends upon careful selection of sampling locations, the timing of sample collection, and the methods of sample collection.

\section{Network Design and Sampling Locations}

The network of snow-sampling sites at high elevations in Montana, Wyoming, Colorado, and New 
Mexico were selected in protected National Forests or National Parks near the Continental Divide. Locations with limited human activity or emissions from local residential, commercial, or industrial infrastructures were chosen for long-term monitoring of regional snowpack-chemistry trends to represent more natural conditions. Avoiding local effects (generally less than $10 \mathrm{~km}$ distant) was necessary to enable sampling for regional emissions that may be detectable hundreds of kilometers from their sources. Most Colorado and New Mexico sites are at elevations ranging from 2,700 to 3,400 m; Wyoming and Montana sites typically are lower at about 1,800 to $2,700 \mathrm{~m}$. At these elevations, the seasonal snowpack accumulates throughout the winter, and substantial snowmelt does not occur until spring runoff begins in March and April. The seasonal snowpacks sampled melt entirely each summer so resampling snowfall from previous years is avoided. As latitude increases along the Continental Divide, the elevation at which seasonal snowpacks persist generally decreases. Snow that survives snowmelt from year to year, referred to as "firn," typically is found only in the highest alpine areas well above treeline and sampling locations in this network.

Severe weather in the Rocky Mountains during late winter and spring and logistical constraints restrict travel at high elevations. Limited access to remote, snow-covered areas requires careful selection of sampling locations. Because no construction of permanent structures or maintenance is necessary using USGS snow-sampling methods described later in this report, sampling locations may be selected in the most optimal locations without permanently affecting wild areas in National Parks and National Forests. The only disturbance at sampling sites is the digging of a small snowpit, which is backfilled just after sample collection. Wind and snowfall events restore smooth, untracked snowscapes soon after sampling visits. Sampling locations are selected that are free from avalanche activity and reasonably accessible to sampling crews. These criteria exclude much of the terrain at the highest elevations of the Rocky Mountains.

Samples were collected in small clearings in forests and on cooler, north-facing slopes whenever possible, and where the snow cover appeared to be free of human effects or other disturbances such as excessive tree litter or animal activity. Each layer sampled was inspected for visible contaminants. Scoured or drifted snowscapes were avoided because such areas would not represent a cumulative seasonal snowpack that contains layers from all snowfall events. Sites were located at least $30 \mathrm{~m}$ away from plowed roadways to minimize contamination from vehicular traffic; other work has shown this distance to be sufficient (Ingersoll, 1999). Consequently, accessibility was limited, and access was by skis, snowshoes, over-snow vehicles, or helicopters.

When possible, snow-sampling sites were collocated with snow-telemetry (SnoTel) instrument sites where measurements of snow-water equivalence (SWE) were reported daily. SnoTel sites, operated by the USDA, Natural Resources Conservation Service, reported other meteorological information describing snowpacks that was useful in choosing sampling locations for the study. Snow depths, total annual snowfall accumulations, air temperature, and total precipitation also were reported daily and historically from a wide network of SnoTel sites throughout the Rocky Mountains (Western Regional Climate Center, 2001).

\section{Timing of Sample Collection}

Sampling was done at about the annual maximum snow depth but before the onset of spring snowmelt. Scheduling field sampling of annual snowpacks near maximum accumulation was based on 30-year-averaged, maximum-SWE values reported at SnoTel sites at similar elevations near the sampling sites. Biweekly SWE values reported at SnoTel sites for the 30-year base period 1961-90 were used to forecast times when snowmelt might begin. Sampling dates were scheduled 2 or 3 weeks before the 30-yearaveraged, maximum SWE period in order to collect samples prior to episodes of earlier-than-usual melting. Timing sample collection this far in advance of the typical beginning of melt from the snowpack increased the likelihood of obtaining an unmelted sample of about 80 to 90 percent of total seasonal snowfall and thus provided a good indicator of atmospheric deposition for a substantial part of the year. Waiting to capture additional snowfall from a few endof-season storms was not worth risking loss of part of the seasonal pack to snowmelt. Obtaining snow samples before melt begins is crucial to preserving the chemical record of the snowpack because the liquid water flowing downward through the snowpack in early stages of snowmelt tends to be more concentrated compared to snowmelt occurring later in the 
process (Campbell and others, 1995; Harrington and Bales, 1998). Because alternating winter and spring weather patterns create substantial fluctuations in air temperatures (40 degrees Celsius in a 24 -hour period), attention to current weather conditions and flexibility for rescheduling field trips is essential to successful snowpack sampling.

\section{Methods of Sample Collection}

Snowpits were prepared with a smooth, freshly cut, vertical, shaded face extending from the ground surface upward throughout the entire depth of the snowpack (fig. 1). Before snow samples were collected, physical measurements of the snowpack were made. Temperature profiles were recorded at 10or 20-centimeter $(\mathrm{cm})$ intervals to ensure temperatures below $0^{\circ} \mathrm{C}$ were present among the snow layers. Snow-

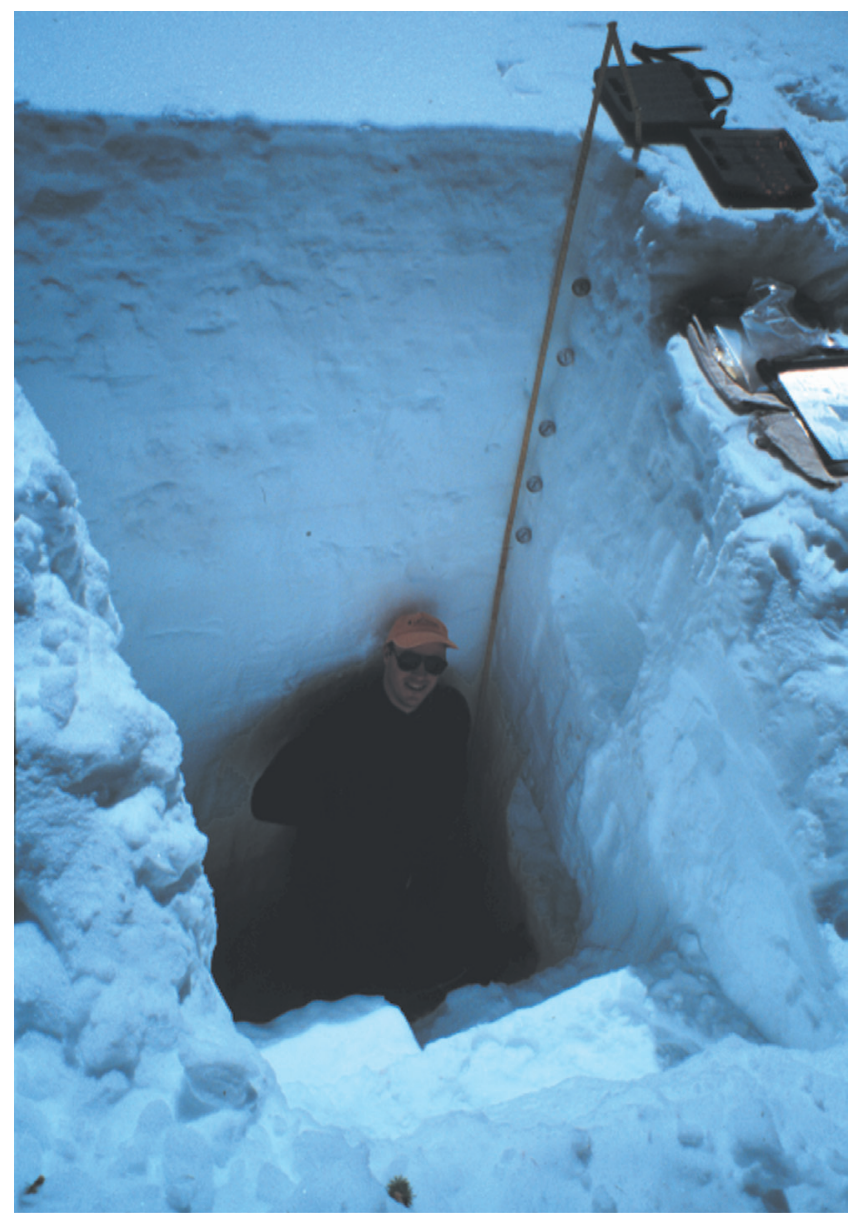

Figure 1. Snowpit face just before sampling the full snowpack. crystal size, type, and hardness of all homogeneous layers were measured to document the metamorphism of the snowpack through the winter. Further observations of ice layers, evidence of melt, saturated wet snow, and soil moisture beneath the snowpack were recorded to verify that snowmelt had not begun and that the snow to be collected maintained the seasonal atmospheric deposition in an ice phase.

Snow samples were collected carefully to prevent contamination. To avoid inclusion of possibly contaminated snow in the samples, the top $5 \mathrm{~cm}$ of snowpack was discarded to exclude snow contaminated by activities resulting from transport to and preparation of the snowpit. The bottom $10 \mathrm{~cm}$ of the snowpack near the ground was not sampled to avoid contamination from soils or other terrestrial materials. Powder-free vinyl laboratory gloves were worn, and clean plastic shovels and scoops were used to collect a complete vertical snow column for each sample.

Workers in the snowpits took precautions to avoid inclusion of potential contaminants such as soils, tree litter, animal waste, or perspiration when filling sample containers. The snow columns were cut and placed in 8-liter (L) Teflon bags and 60-L plastic carboys that were prerinsed with high-purity deionized water. These containers were sealed to prevent contamination and transported to a USGS research laboratory in Boulder, Colo., for analysis. The 8-L samples were kept frozen to prevent chemical reactivity prior to laboratory analyses for major ions and trace metals. The $60-\mathrm{L}$ samples, reserved strictly for analysis of stable sulfur isotopic ratios, were allowed to attain room temperature from the time of collection until analyses were done. Similar samples for nitrogen isotopes were kept cold, transported to a freezer as soon as possible, and kept frozen prior to analysis to inhibit transformation of nitrogen ions. Isotope analyses are discussed in detail by Campbell and others (in press) and Mast and others (2001). Laboratory methods and quality-assurance procedures for major-ion analyses are described in Ingersoll (1999). Ionic charge balance was calculated for each of five annual samples by calculating the sum of cations (hydrogen ion, calcium, magnesium, sodium, potassium, and ammonium) minus the sum of anions (alkalinity, chloride, nitrate, and sulfate) divided by the total cations and anions in solution. Alkalinities were predominantly negative for the snow samples analyzed in this study; only positive values for alkalinity were included with the sum of anions in charge-balance calculations. 


\section{RESULTS OF MONITORING}

For each of the 5 years (1993-97), samples were collected at each of the 52 sampling sites in the network with one exception. Due to complications reaching the center of the restricted Flat Tops Wilderness Area, substitution for the 1996 and 1997 samples for the Ned Wilson site was made by relocating to a nearby site at a similar elevation about $10 \mathrm{~km}$ away at Trappers Lake. In a few cases, the snowpack had warmed to near-isothermal levels throughout, but no substantial snowmelt had begun before samples were collected. Typical water contents measured in the annual snowpacks in the study area ranged from about $0.2 \mathrm{~m}$ in the drier areas to about $1.7 \mathrm{~m}$ in the deepest snowpacks during 1993-97.

Average values (1993-97) for concentrations of major ions, alkalinity, dissolved organic carbon, and ionic charge balances and median values of laboratory $\mathrm{pH}$ are listed in table 1. Ionic charge balances mostly were positive with a mean of +9.4 percent. Other ionic balances calculated for precipitation chemistry of comparable ionic strength in a separate network yielded similar deviations (National Atmospheric Deposition Program, 1993). One explanation for the positive bias for the ionic balances (table 1) is that organic acids were not included in the calculation. However, selected organic acids were analyzed at a subset of sites in this network (30 percent to 70 percent depending on the constituent). Mean concentrations of acetate and formate were 1.2 and 0.6 microequivalents per liter, respectively (Turk and others, 2001), and if included in calculations, would decrease positive ionic balances by roughly 3 to 5 percent.

\section{Regional Monitoring}

Using annual snowpack chemistry as an indicator of sources of airborne pollutants functions effectively on both regional and local scales. Regionally, concentrations of the acid-forming ion of nitrate and sulfate generally were lower in northern Wyoming and western Montana when compared to concentrations in samples from southern Wyoming and northern Colorado (table 1, figs. 2-4). As a group, the snowpacks in northern Colorado that lie adjacent to both the highly developed Denver metropolitan area to the east and the coal-fired powerplants to the west had the highest overall concentrations of nitrate and sulfate. Specifically, the lowest $\mathrm{pH}$ and highest concentrations of nitrate and sulfate in seasonal snowpacks in the Rocky Mountain region were at two sites in the mountains of northwestern Colorado. Although flow directions of surface winds in the Rocky Mountains are variable and fluctuate on an hourly basis, prevailing westerly winds dominate in this area (Banta and Cotton, 1981; Barry, 1992). The Dry Lake and Buffalo Pass sites are located downwind (east) from local coal-fired power generation (Turk and Campbell, 1997) and 140-160 km upwind (west) from the Denver metropolitan area. Products of fossil-fuel combustion such as nitrate and sulfate in snowpacks at these two sites downwind from the local powerplants were as much as three times higher than levels in snowpacks elsewhere in Colorado (Ingersoll, 1995; 1996). Ammonium concentrations were highest in northwestern Wyoming and southern Montana. Detailed discussions of these patterns for 1993-97 are given by Turk and others (2001).

Although sulfur dioxide emissions nationwide have decreased in the past decade, nitrogen oxide emissions have not (U.S. Environmental Protection Agency, 1999; Nilles and Conley, 2001). In the mountains of northern Colorado nearer to Denver, increasing evidence indicates that excess nitrogen entering ecosystems is causing nitrogen saturation. Heuer and others (2000) determined that nitrogen concentrations measured during the years 1992-97 in precipitation at NADP sites mostly within $200 \mathrm{~km}$ of Denver were consistently higher than NADP sites farther from Denver. Other work has shown similarly elevated levels of nitrogen deposition to mountain ecosystems within this distance from Denver (Williams and others, 1996; Campbell and others, 2000). These findings agree with the regional spatial patterns of snowpack nitrate shown in figure 3. Such patterns in nitrate concentrations in snowpacks also show increased nitrogen deposition is occurring near the largest sources such as powerplants and large population centers.

\section{Local Monitoring}

On a local scale, monitoring the effects of snowmobiling on snowpack chemistry in Yellowstone National Park is an example of how chemicals deposited into a snowpack may be linked to their source. A relation between chemical concentrations of ammonium and sulfate in seasonal snowpacks and the level 
Table 1. Five-year average values (1993-97) for concentrations of major ions, alkalinity, dissolved organic carbon, and ionic charge balances and median values of laboratory $\mathrm{pH}$

[5-year means for hydrogen $\left(\mathrm{H}^{+}\right)$, calcium $\left(\mathrm{Ca}^{2+}\right)$, magnesium $\left(\mathrm{Mg}^{2+}\right)$, sodium $\left(\mathrm{Na}^{+}\right)$, potassium $\left(\mathrm{K}^{+}\right)$, ammonium $\left(\mathrm{NH}_{4}^{+}\right)$, chloride $\left(\mathrm{Cl}^{-}\right)$, sulfate $\left(\mathrm{SO}_{4}{ }^{2-}\right)$, nitrate $\left(\mathrm{NO}_{3}{ }^{-}\right)$, and alkalinity (Alk) are in microequivalents per liter; dissolved organic carbon (DOC) values expressed in milligrams per liter. $\mathrm{pH}$ values are 5 -year medians; ionic balances are percentages]

\begin{tabular}{|c|c|c|c|c|c|c|c|c|c|c|c|c|c|c|}
\hline $\begin{array}{c}\text { Site } \\
\text { number } \\
\text { shown } \\
\text { in figs. } \\
2-4\end{array}$ & Site name & $\mathrm{pH}$ & $\mathrm{H}^{+}$ & $\mathrm{Ca}^{2+}$ & $\mathrm{Mg}^{2+}$ & $\mathrm{Na}^{+}$ & $\mathrm{K}^{+}$ & $\mathrm{NH}_{4}^{+}$ & $\mathrm{Cl}^{-}$ & $\mathrm{SO}_{4}{ }^{2-}$ & $\mathrm{NO}_{3}^{-}$ & Alk & DOC & $\begin{array}{l}\text { lonic } \\
\text { bal- } \\
\text { ance }\end{array}$ \\
\hline 1 & $\begin{array}{l}\text { Big Mountain, } \\
\text { Mont. }\end{array}$ & 5.11 & 7.3 & 1.3 & $<0.3$ & $<0.9$ & $<0.3$ & 2.9 & 0.7 & 4.1 & 4.7 & -8.2 & 0.6 & 15.7 \\
\hline 2 & Big Sky, Mont. & 5.42 & 3.3 & 4.9 & 1.0 & 2.1 & 0.6 & 4.1 & 0.9 & 4.7 & 5.6 & -1.0 & 0.6 & 16.9 \\
\hline 4 & $\begin{array}{l}\text { Daisy Pass, } \\
\text { Mont. }\end{array}$ & 5.29 & 4.8 & 2.4 & 0.6 & $<0.9$ & 0.7 & 3.5 & 0.8 & 4.0 & 4.2 & -5.8 & 0.5 & 17.6 \\
\hline 5 & $\begin{array}{l}\text { Granite Pass, } \\
\text { Mont. }\end{array}$ & 5.31 & 4.5 & 0.9 & 0.3 & $<0.7$ & 0.6 & 1.4 & 0.8 & 2.5 & 2.3 & -4.6 & 0.7 & 20.4 \\
\hline 6 & $\begin{array}{l}\text { Kings Hill, } \\
\text { Mont. }\end{array}$ & 5.33 & 5.1 & 4.4 & 0.7 & 1.0 & 0.5 & 5.6 & 1.1 & 6.6 & 6.2 & -5.9 & 0.9 & 10.8 \\
\hline 9 & $\begin{array}{l}\text { Red Mountain, } \\
\text { Mont. }\end{array}$ & 5.55 & 3.5 & 4.2 & 1.0 & 1.4 & 0.7 & 4.6 & 0.9 & 4.5 & 5.5 & -3.8 & 0.9 & 14.7 \\
\hline 10 & $\begin{array}{c}\text { Snow Bowl, } \\
\text { Mont. }\end{array}$ & 5.21 & 6.1 & 1.7 & 0.5 & $<0.9$ & 0.8 & 2.9 & 1.0 & 4.0 & 4.0 & -7.1 & 0.8 & 17.3 \\
\hline 11 & $\begin{array}{l}\text { West Yellow- } \\
\text { stone, Mont. }\end{array}$ & 5.23 & 5.1 & 2.8 & 0.9 & $<0.7$ & 1.0 & 7.0 & 1.9 & 4.9 & 8.0 & -5.4 & 0.8 & 7.8 \\
\hline 12 & $\begin{array}{l}\text { Brooklyn } \\
\text { Lake, Wyo. }\end{array}$ & 5.02 & 8.3 & 5.6 & 1.4 & 1.2 & 0.9 & 4.0 & 1.2 & 8.5 & 10.0 & -9.3 & 1.0 & 4.3 \\
\hline 17 & $\begin{array}{l}\text { Garnet } \\
\text { Canyon, } \\
\text { Wyo. }\end{array}$ & 5.21 & 5.8 & 2.5 & 0.8 & 1.0 & 0.6 & 3.7 & 0.9 & 4.7 & 4.9 & -5.7 & 0.4 & 16.4 \\
\hline 18 & $\begin{array}{l}\text { Gypsum } \\
\text { Creek, Wyo. }\end{array}$ & 5.17 & 6.1 & 3.7 & 1.3 & 1.5 & 1.0 & 3.3 & 1.2 & 5.1 & 6.8 & -6.6 & 0.8 & 11.1 \\
\hline 19 & $\begin{array}{l}\text { Lewis Lake } \\
\text { Divide, } \\
\text { Wyo. }\end{array}$ & 5.34 & 4.5 & 2.1 & 0.8 & $<0.7$ & 0.4 & 5.7 & 1.1 & 4.5 & 5.6 & -4.7 & 0.6 & 11.1 \\
\hline 20 & $\begin{array}{l}\text { Old Battle, } \\
\text { Wyo. }\end{array}$ & 4.96 & 8.8 & 6.4 & 1.6 & 1.3 & 1.1 & 4.7 & 1.2 & 9.7 & 10.6 & -7.9 & 0.9 & 5.2 \\
\hline 21 & $\begin{array}{l}\text { Rendezvous } \\
\text { Mountain, } \\
\text { Wyo. }\end{array}$ & 5.21 & 5.2 & 3.6 & 1.0 & 1.1 & 0.3 & 3.2 & 0.9 & 5.3 & 5.1 & -3.9 & 0.5 & 2.5 \\
\hline
\end{tabular}


Table 1. Five-year average values (1993-97) for concentrations of major ions, alkalinity, dissolved organic carbon, and ionic charge balances and median values of laboratory $\mathrm{pH}-$ Continued

[5-year means for hydrogen $\left(\mathrm{H}^{+}\right)$, calcium $\left(\mathrm{Ca}^{2+}\right)$, magnesium $\left(\mathrm{Mg}^{2+}\right)$, sodium $\left(\mathrm{Na}^{+}\right)$, potassium $\left(\mathrm{K}^{+}\right)$, ammonium $\left(\mathrm{NH}_{4}^{+}\right)$, chloride $\left(\mathrm{Cl}^{-}\right)$, sulfate $\left(\mathrm{SO}_{4}{ }^{2-}\right)$, nitrate $\left(\mathrm{NO}_{3}{ }^{-}\right)$, and alkalinity (Alk) are in microequivalents per liter; dissolved organic carbon (DOC) values expressed in milligrams per liter. $\mathrm{pH}$ values are 5 -year medians; ionic balances are percentages]

\begin{tabular}{|c|c|c|c|c|c|c|c|c|c|c|c|c|c|c|}
\hline $\begin{array}{c}\text { Site } \\
\text { number } \\
\text { shown } \\
\text { in figs. } \\
2-4\end{array}$ & Site name & $\mathrm{pH}$ & $\mathrm{H}^{+}$ & $\mathrm{Ca}^{2+}$ & $\mathrm{Mg}^{2+}$ & $\mathrm{Na}^{+}$ & $\mathrm{K}^{+}$ & $\mathrm{NH}_{4}^{+}$ & $\mathrm{Cl}^{-}$ & $\mathrm{SO}_{4}{ }^{2-}$ & $\mathrm{NO}_{3}{ }^{-}$ & Alk & DOC & $\begin{array}{c}\text { Ionic } \\
\text { bal- } \\
\text { ance }\end{array}$ \\
\hline 22 & $\begin{array}{l}\text { South Pass, } \\
\text { Wyo. }\end{array}$ & 5.13 & 7.2 & 6.3 & 1.6 & 2.7 & 0.9 & 4.2 & 1.2 & 9.4 & 8.8 & -6.4 & 0.9 & 1.5 \\
\hline 23 & $\begin{array}{l}\text { Sylvan Lake, } \\
\text { Wyo. }\end{array}$ & 5.33 & 4.9 & 2.2 & 0.6 & 1.3 & 0.6 & 4.4 & 1.1 & 4.6 & 4.7 & -5.3 & 0.6 & 14.8 \\
\hline 25 & $\begin{array}{l}\text { Togwotee Pass, } \\
\text { Wyo. }\end{array}$ & 5.44 & 3.6 & 4.0 & 0.9 & 2.1 & 0.5 & 3.1 & 1.0 & 4.5 & 4.5 & -4.2 & 0.6 & 18.2 \\
\hline 26 & $\begin{array}{l}\text { Twenty-one } \\
\text { Mile, Wyo. }\end{array}$ & 5.23 & 6.3 & 2.7 & 0.7 & 1.2 & 0.6 & 5.2 & 1.9 & 4.7 & 6.6 & -6.9 & 0.7 & 10.4 \\
\hline 29 & $\begin{array}{l}\text { Buffalo Pass, } \\
\text { Colo. }\end{array}$ & 4.87 & 11.1 & 5.3 & 1.3 & 1.4 & $<0.3$ & 5.2 & 1.0 & 10.9 & 10.6 & -10.7 & 0.6 & 2.1 \\
\hline 30 & $\begin{array}{l}\text { Cameron Pass, } \\
\text { Colo. }\end{array}$ & 5.00 & 9.4 & 5.2 & 1.1 & 2.1 & 1.0 & 3.6 & 1.7 & 7.4 & 9.0 & -10.0 & 0.9 & 10.7 \\
\hline 31 & $\begin{array}{l}\text { Deadman Pass, } \\
\text { Colo. }\end{array}$ & 5.29 & 5.1 & 9.3 & 2.4 & 1.1 & 3.0 & 4.8 & 1.4 & 8.6 & 10.6 & -0.3 & 2.3 & 0.8 \\
\hline 32 & $\begin{array}{l}\text { Dry Lake, } \\
\text { Colo. }\end{array}$ & 4.81 & 15.2 & 6.4 & 1.5 & 1.3 & 1.1 & 4.8 & 1.2 & 11.4 & 15.1 & -16.8 & 0.8 & 4.4 \\
\hline 33 & $\begin{array}{l}\text { Dunckley Pass, } \\
\text { Colo. }\end{array}$ & 5.40 & 5.0 & 10.6 & 2.0 & 1.3 & 2.5 & 3.9 & 1.4 & 7.6 & 10.1 & -5.0 & 0.9 & 6.9 \\
\hline 38 & $\begin{array}{l}\text { Loch Vale, } \\
\text { Colo. }\end{array}$ & 4.99 & 9.4 & 5.8 & 1.4 & 1.5 & 0.9 & 4.2 & 1.0 & 8.3 & 10.6 & -10.3 & 0.9 & 6.7 \\
\hline 39 & $\begin{array}{l}\text { Loveland Pass, } \\
\text { Colo. }\end{array}$ & 5.42 & 4.5 & 7.5 & 1.7 & 2.9 & 1.3 & 2.9 & 2.2 & 5.7 & 8.4 & -3.4 & 1.9 & 9.8 \\
\hline 40 & $\begin{array}{l}\text { Lynx Pass, } \\
\text { Colo. }\end{array}$ & 4.99 & 10.6 & 4.4 & 1.1 & 1.2 & 0.4 & 2.6 & 0.8 & 6.2 & 10.3 & -14.2 & 0.6 & 7.2 \\
\hline 41 & $\begin{array}{l}\text { Molas Lake, } \\
\text { Colo. }\end{array}$ & 5.54 & 3.6 & 11.3 & 1.4 & 1.4 & 2.4 & 2.8 & 1.3 & 5.8 & 7.7 & 0.3 & 1.0 & 2.6 \\
\hline 42 & $\begin{array}{l}\text { Monarch Pass, } \\
\text { Colo. }\end{array}$ & 5.64 & 2.7 & 12.0 & 1.9 & 1.1 & 1.5 & 3.4 & 1.1 & 6.4 & 8.4 & -1.4 & 1.1 & 6.6 \\
\hline 43 & $\begin{array}{l}\text { Phantom } \\
\text { Valley, Colo. }\end{array}$ & 4.91 & 10.5 & 4.6 & 1.3 & 1.9 & 0.9 & 4.0 & 1.2 & 7.8 & 10.0 & -11.5 & 1.0 & 9.5 \\
\hline
\end{tabular}


Table 1. Five-year average values (1993-97) for concentrations of major ions, alkalinity, dissolved organic carbon, and ionic charge balances and median values of laboratory $\mathrm{pH}-$ Continued

[5-year means for hydrogen $\left(\mathrm{H}^{+}\right)$, calcium $\left(\mathrm{Ca}^{2+}\right)$, magnesium $\left(\mathrm{Mg}^{2+}\right)$, sodium $\left(\mathrm{Na}^{+}\right)$, potassium $\left(\mathrm{K}^{+}\right)$, ammonium $\left(\mathrm{NH}_{4}{ }^{+}\right)$, chloride $\left(\mathrm{Cl}^{-}\right)$, sulfate $\left(\mathrm{SO}_{4}{ }^{2-}\right)$, nitrate $\left(\mathrm{NO}_{3}^{-}\right)$, and alkalinity (Alk) are in microequivalents per liter; dissolved organic carbon (DOC) values expressed in milligrams per liter. pH values are 5-year medians; ionic balances are percentages]

\begin{tabular}{|c|c|c|c|c|c|c|c|c|c|c|c|c|c|c|}
\hline $\begin{array}{c}\text { Site } \\
\text { number } \\
\text { shown } \\
\text { in figs. } \\
2-4\end{array}$ & Site name & $\mathrm{pH}$ & $\mathrm{H}^{+}$ & $\mathrm{Ca}^{2+}$ & $\mathrm{Mg}^{2+}$ & $\mathrm{Na}^{+}$ & $\mathrm{K}^{+}$ & $\mathrm{NH}_{4}^{+}$ & $\mathrm{Cl}^{-}$ & $\mathrm{SO}_{4}{ }^{2-}$ & $\mathrm{NO}_{3}{ }^{-}$ & Alk & DOC & $\begin{array}{c}\text { lonic } \\
\text { bal- } \\
\text { ance }\end{array}$ \\
\hline 44 & $\begin{array}{l}\text { Rabbit Ears } \\
\text { Pass, Colo. }\end{array}$ & 4.87 & 12.4 & 4.5 & 0.9 & 1.4 & 0.4 & 4.6 & 1.0 & 10.6 & 10.4 & -12.8 & 0.6 & 4.7 \\
\hline 45 & $\begin{array}{l}\text { Red Mountain } \\
\text { Pass, Colo. }\end{array}$ & 5.42 & 3.1 & 13.9 & 2.2 & 1.3 & 1.5 & 3.0 & 1.3 & 6.1 & 8.2 & 1.5 & 0.8 & 6.6 \\
\hline 47 & $\begin{array}{l}\text { Sunlight Peak, } \\
\text { Colo. }\end{array}$ & 5.16 & 5.7 & 7.9 & 1.8 & 1.0 & 1.2 & 4.4 & 0.9 & 7.1 & 9.2 & -7.0 & 0.8 & 11.7 \\
\hline 48 & $\begin{array}{l}\text { Trappers Lake, } \\
\text { Colo. }\end{array}$ & 5.41 & 4.3 & 7.2 & 1.3 & 1.3 & 0.7 & 3.1 & 1.3 & 6.0 & 8.0 & -5.0 & 0.8 & 7.7 \\
\hline 51 & $\begin{array}{l}\text { Gallegos Peak, } \\
\text { N. Mex. }\end{array}$ & 5.26 & 4.6 & 13.7 & 2.5 & 1.4 & 2.7 & 4.1 & 1.3 & 9.2 & 9.0 & -2.3 & 1.3 & 7.3 \\
\hline \multirow[t]{4}{*}{52} & $\begin{array}{l}\text { Hopewell, N. } \\
\text { Mex. }\end{array}$ & 5.14 & 6.1 & 11.7 & 1.8 & 1.1 & 1.5 & 4.5 & 1.2 & 9.1 & 10.8 & -4.1 & 0.9 & 2.6 \\
\hline & \multicolumn{14}{|l|}{$\begin{array}{c}\text { Summary } \\
\text { statistics }\end{array}$} \\
\hline & minimum & 4.81 & 2.0 & 0.9 & 0.3 & 1.0 & 0.3 & 1.4 & 0.7 & 2.5 & 2.3 & -16.8 & 0.4 & -0.2 \\
\hline & maximum & 5.69 & 15.2 & 13.9 & 3.5 & 3.9 & 3.0 & 13.3 & 3.1 & 11.4 & 15.1 & 7.7 & 2.4 & 20.6 \\
\hline
\end{tabular}

Footnotes:

${ }^{1}$ Cation, anion, alkalinity (microequivalents per liter), and DOC values (milligrams per liter) are 5-year means.

$2 \mathrm{pH}$ values are 5-year medians.

${ }^{3}$ Percentages for ionic balances are mean values of individual annual calculations of charge balance of [(total cations - total anions)/(total cations + total anions) $] \times 100$.

${ }^{4}$ Positive alkalinities are included in total anions; negative values are excluded.

${ }^{5}$ Censored data denoted by " $<$ " were used in summary statistics but indicate values below detection limits.

${ }^{6}$ Site number corresponds to sites shown in figures $2-4$. 


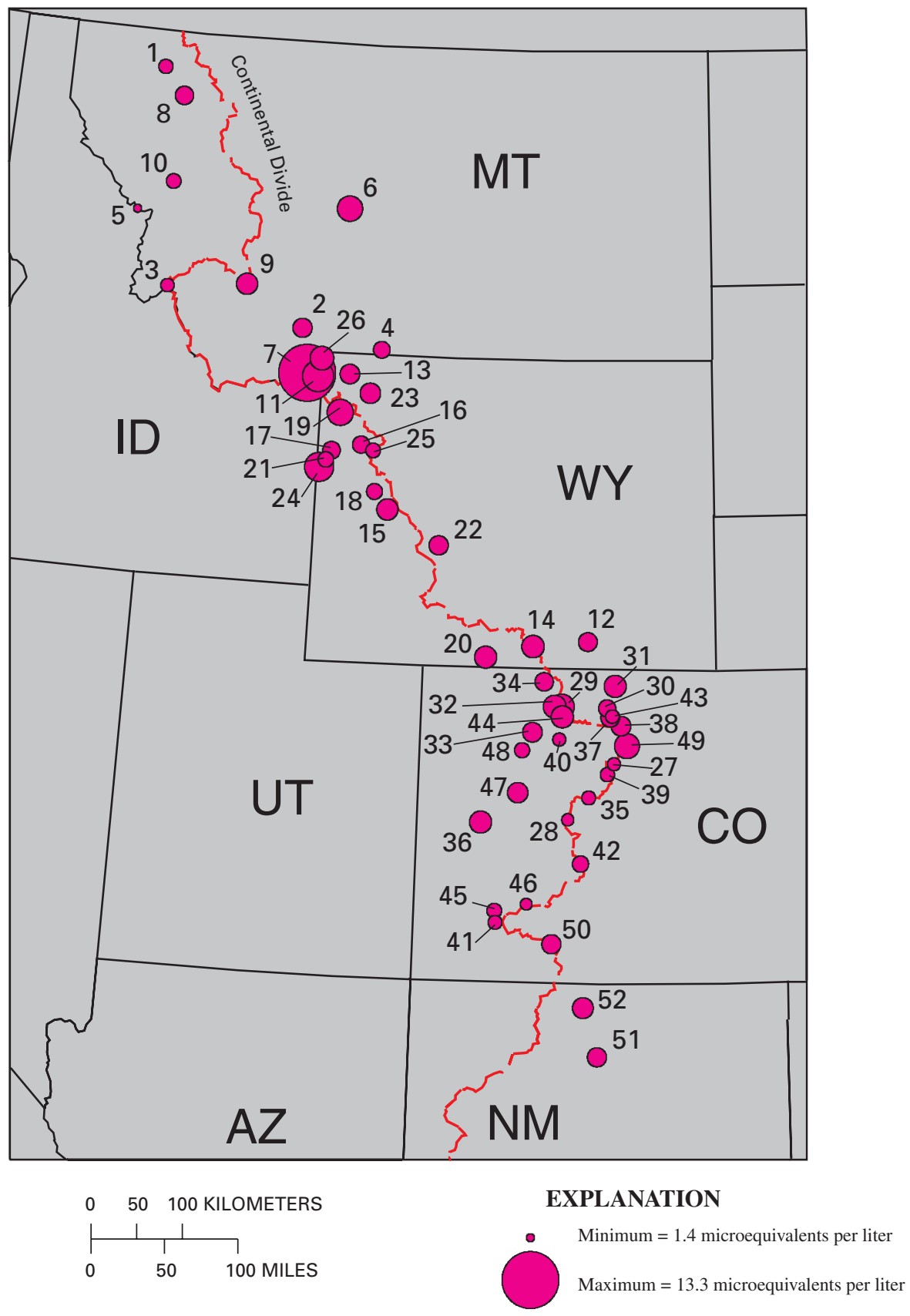

Figure 2. Average ammonium ion concentrations in snowpack, 1993-97.

of snowmobile usage in Yellowstone National Park has been established over short distances (Ingersoll, 1999). Snow chemistry at sampling sites in snowpacked roadways along high-traffic snowmobile routes showed consistently higher concentrations of ammonium and sulfate than snow samples collected at sites $30 \mathrm{~m}$ or more offroad from the sampling sites in snowmobile routes. Sites at Biscuit Basin, Old Faithful, West Yellowstone, and West Yellowstone-8km were chosen to represent high levels of snowmobile traffic; sites at Lewis Lake and Sylvan Lake represent moderate-to-low traffic levels. Spots indicating ammonium concentrations detected for these six pairs of samples collected in 1998 are connected by a vertical line, and offroad sites are shown above in-road sites for comparison in figure 5 (for more detail, see Ingersoll, 1999). Even in areas with substantial local exhaust emissions from snowmobiles (like West Yellowstone and Old Faithful), this sampling method allows using the nearby offroad snowpack chemistry in the regional assessment of emissions from larger, regional sources (such as powerplants or other 


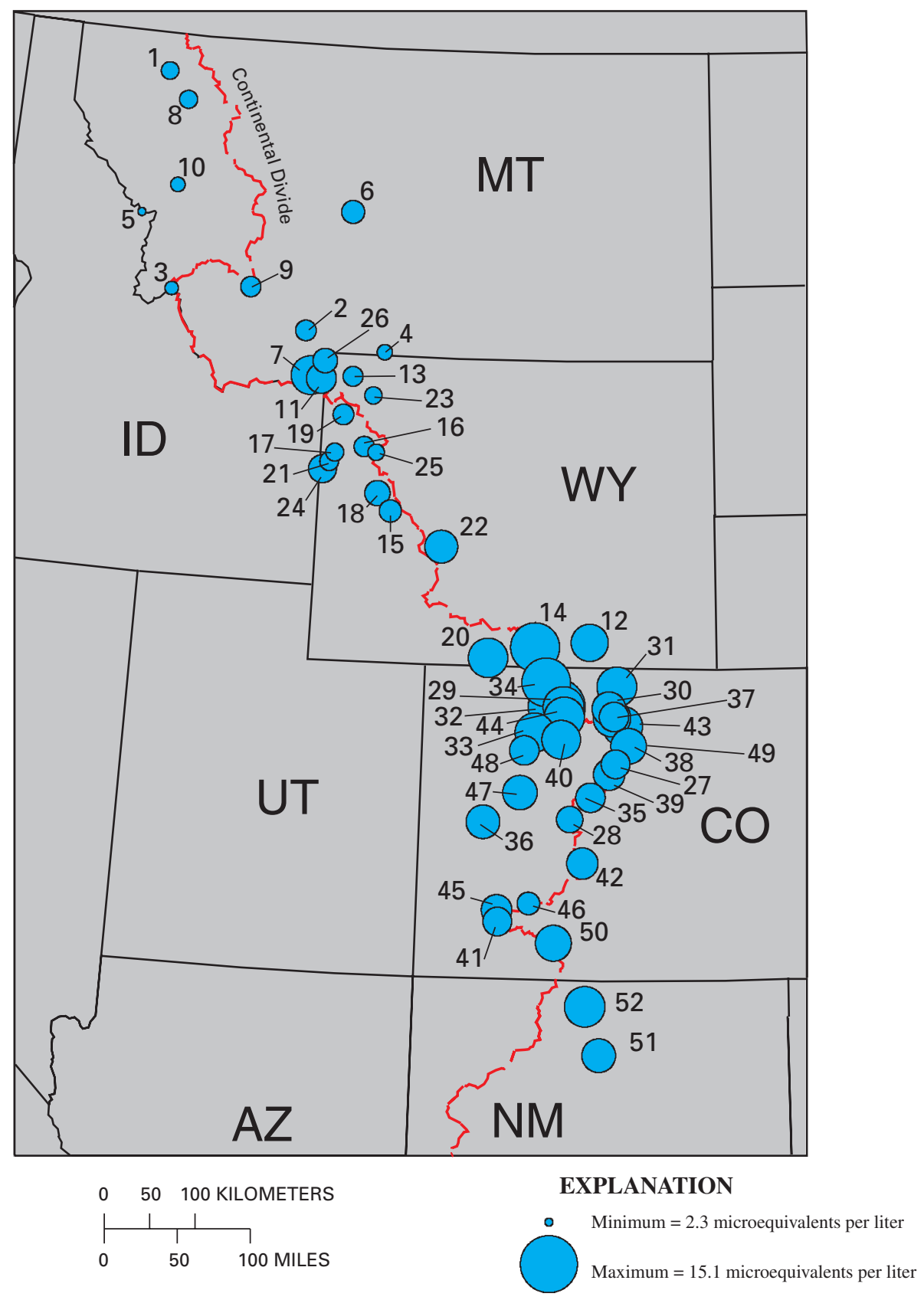

Figure 3. Average nitrate ion concentrations in snowpack, 1993-97.

industrial production) without interference from such local emissions. Because snowmobile emissions tend to be limited in dispersion and confined to specific corridors in many heavy-use areas, snow-sampling sites $30 \mathrm{~m}$ away from that local effect are representative of regional snow chemistry. This distinction is important to site selection for regional snowpack chemical interpretation because snowmobiling is widespread throughout the Rocky Mountains.
After 5 years of monitoring annual snowpack chemistry, spatial patterns in regional data have emerged from the geographically distributed chemical concentrations that clearly indicate low concentrations of acid precursors in less developed areas of the region and high concentrations in the heavily developed areas. Although local effects, such as snowmobile emissions, are detectable in popular snowmobiling areas of the Rocky Mountain region, the contribution to regional atmospheric deposition likely is minimal. 


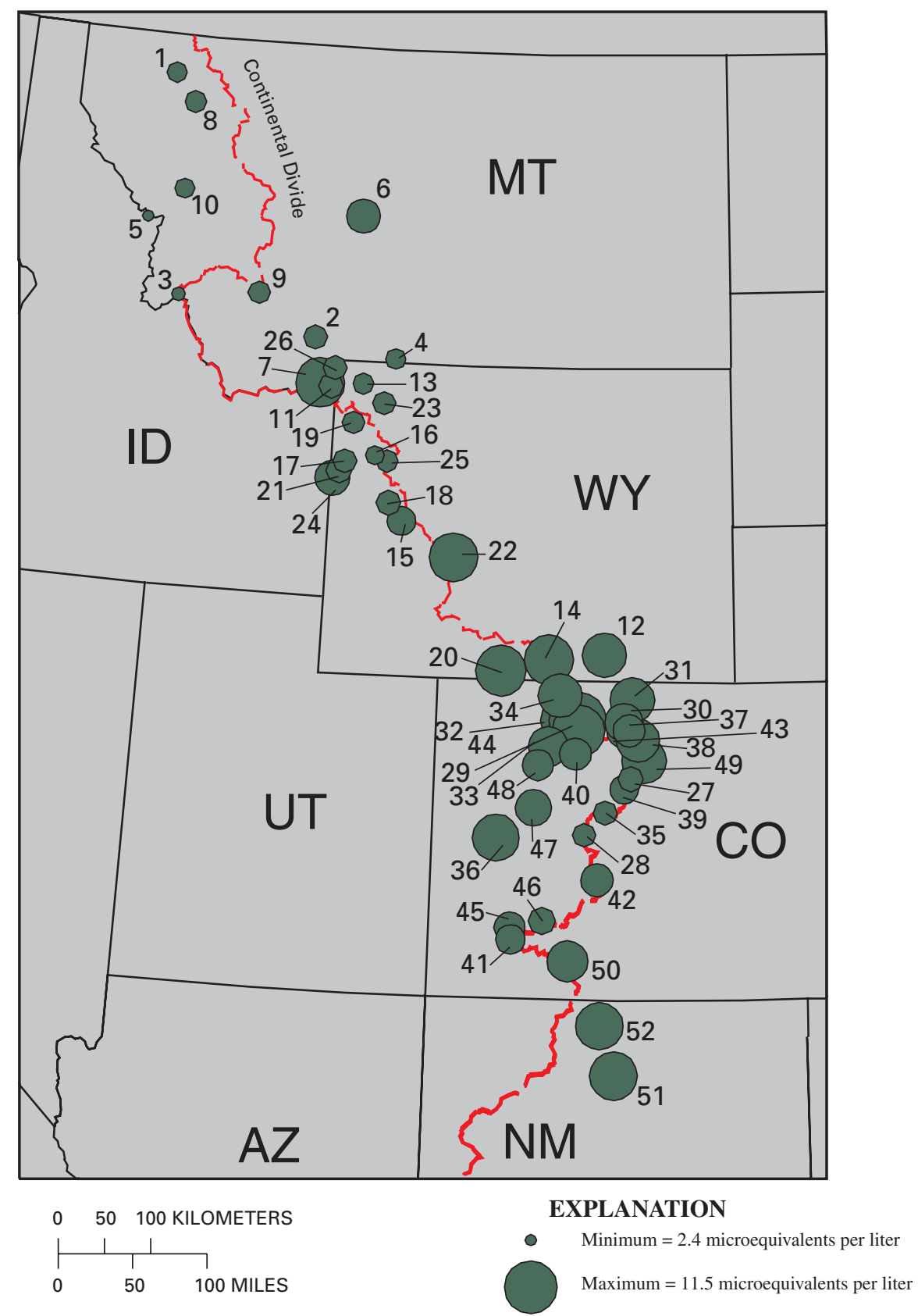

Figure 4. Average sulfate ion concentrations in snowpack, 1993-97.

\section{IMPORTANCE OF LONG-TERM MONITORING}

This study of the chemistry of regional snowpacks establishes regional ranges of ammonium concentrations in high-elevation areas along the Continental Divide from northern New Mexico to northern Montana (table 1). Using established sampling and analytical protocols for all sites throughout the network each year, we are building a reliable, long- term record of the effects on snowpack chemistry of atmospheric deposition to the Rocky Mountain region. As this snowpack-chemistry network continues, we gain the advantages of more robust trend evaluation, increasing confidence in apparent trends, and reinforcing reliable estimates of high, low, or average concentrations. Established background concentrations at sampling locations minimally affected by airborne pollutants are substantiated by successive years when consistently low chemical concentrations 


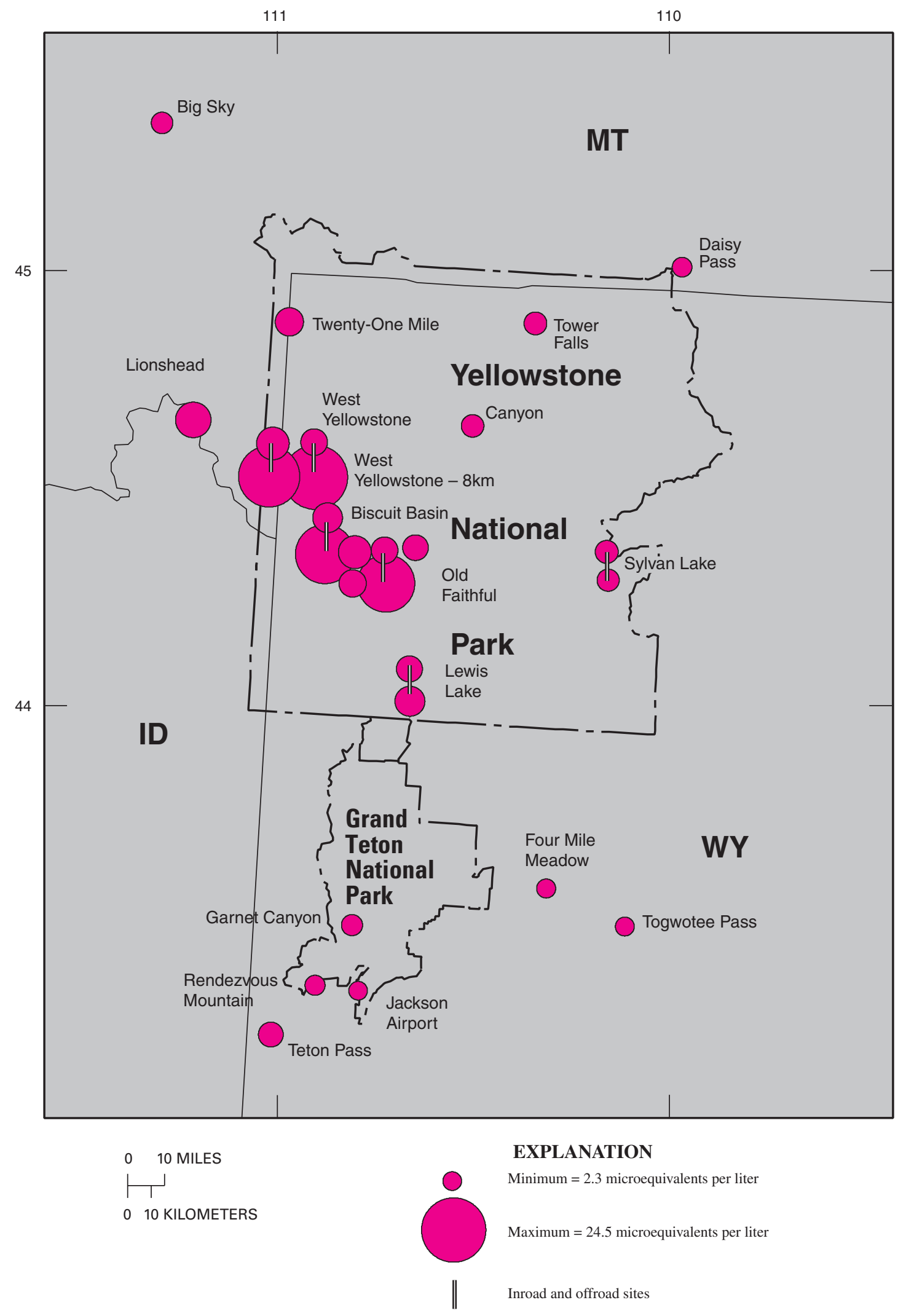

Figure 5. Ammonium ion concentrations in snowpack in the Greater Yellowstone area, 1998. 
were detected. Accordingly, identification of sites where concentrations are considerably higher can be done with greater confidence. This may be especially true for more gradual changes in emissions. Whether decreases or increases in regional air-pollutant emissions occur in the Rocky Mountains in the coming years, the rate should be identified and the trends monitored.

If reductions in emissions of sulfur dioxide from developed areas and power production facilities continue nationally (U.S. Environmental Protection Agency, 1999), downward trends in regional concentrations of sulfate deposition should be reflected in annual snowpack chemistry. Such results would be particularly meaningful in areas where costly emissions-reductions programs are enacted, such as at coalfired powerplants or large urban centers. Monitoring the present trend of nitrogen emissions and the occurrence of nitrogen saturation in some mountain ecosystems also is important for protection of these wilderness areas. Further, the snowpack-chemistry network is continuing into 2002 and evolving with new focus on other contaminants of recent concern in the region, such as pesticides and mercury. Continuation of this snowpack-monitoring network will support future evaluation of trends in atmospheric-deposition chemistry, modeling of estimated deposition if new emissions sources are to be permitted, and quantification of progress made toward emissions reductions. Without such a monitoring effort, detection of inputs from atmospheric deposition to sensitive mountain environments over the expansive Rocky Mountain region will be limited.

\section{Acknowledgments}

The authors are grateful for the cooperation from numerous individuals from many organizations including Colorado Department of Public Health and Environment; National Park Service; Public Service Company of Colorado; Routt County, Colorado; Tri-State Generation and Transmission Association; U.S. Department of Agriculture Forest Service, and the U.S. Environmental Protection Agency, all of which made this study possible.

\section{REFERENCES}

Baron, J.S., ed., 1992, Biogeochemistry of a subalpine ecosystem-Loch Vale watershed: New York, Springer-Verlag, 247 p.

Barry, R.G., 1992, Mountain weather and climate, 2d ed.: London, Routledge, p. 226-259.

Banta, R., and Cotton, W.R., 1981, An analysis of the structure of local wind systems in a broad mountain basin: Journal of Applied Meteorology, v. 20, p. 1255-1266.

Caine, N., and Thurman, E.M., 1990, Temporal and spatial variations in the solute content of an alpine stream, Colorado Front Range: Geomorphology, v. 4, p. 55-72.

Campbell, D.H., Baron, J.S., Tonnessen, K.A., Brooks, P.D., and Schuster, P.F., 2000, Controls on nitrogen flux in alpine/subalpine watersheds of Colorado: Water Resources Research, v. 36, p. 37-47.

Campbell, D.H., Clow, D.W., Ingersoll, G.P., Mast, M.A., Spahr, N.E., and Turk, J.T., 1995, Processes controlling the chemistry of two snowmelt-dominated streams in the Rocky Mountains: Water Resources Research, v. 31, p. 2811-2821.

Campbell, D.H., Kendall, C., Chang, C.C.Y., Silva, S.R., and Tonnessen, K.A., in press, Pathways for nitrate release from an alpine watershed-determination using del- ${ }^{15} \mathrm{~N}$ and del- ${ }^{18} \mathrm{O}$, Water Resources Research.

Campbell, D.H., Turk, J.T., and Spahr, N.E., 1991, Response of Ned Wilson Lake watershed, Colorado, to changes in atmospheric deposition of sulfate: Water Resources Research, v. 27, p. 2047-2060.

Cogbill, C.V., and Likens, G.E., 1974, Acid precipitation in the Northeastern United States: Water Resources Research, v. 10, p. 1133-1137.

Corn, P.S., Stolzenburg, W., and Bury, R.B., 1989, Acid precipitation studies in Colorado and WyomingInterim report of surveys of montane amphibians and water chemistry: Fort Collins, Colo., U.S. Fish and Wildlife Service, National Ecology Research Center, Ecology and Systematics Section, 56 p.

Harrington, R., and Bales, R.C., 1998, Interannual, seasonal, and spatial patterns of meltwater and solute fluxes in a seasonal snowpack: Water Resources Research, v. 34, p. 823-831.

Heuer, K., Tonnessen, K.A., and Ingersoll, G.P., 2000, Comparison of precipitation chemistry in the Central Rocky Mountains, Colorado, USA: Atmospheric Environment, v. 34, p. 1713-1722.

Ingersoll, G.P., 1995, Maximum-accumulation snowpack chemistry at selected sites in northwestern Colorado during spring 1994: U.S. Geological Survey Open-File Report 95-139, 14 p. 
Ingersoll, G.P., 1996, Snowpack chemistry at selected sites in northwestern Colorado during spring 1995: U.S. Geological Survey Open-File Report 96-411, 16 p.

Ingersoll, G.P., 1999, Effects of snowmobile use on snowpack chemistry in Yellowstone National Park, 1998: U.S. Geological Survey Water-Resources Investigations Report 99-4148, 23 p.

Kendall, C., Campbell, D.H., Burns, D.A., Shanley, J.B., Silva, S.R., Chang, C.C.Y., 1995, Tracing sources of nitrate in snowmelt runoff using the oxygen and nitrogen isotopic concentrations of nitrate, in Tonnessen, K., Williams, M., and Tranter, M., eds., Biogeochemistry of seasonally-snowcovered catchments: International Association of Hydrological Science Proceedings, July 3-14, 1995, Boulder, Colo.

Mast, M.A., Turk, J.T., Ingersoll, G.P., Clow, D.W., and Kester, C., 2001, Use of stable sulfur isotopes to identify sources of sulfate in Rocky Mountain snowpacks: Atmospheric Environment, v. 35, p. 3303-3313.

National Atmospheric Deposition Program (NADP), http://nadp.sws.uiuc.edu/ (accessed August 2001).

National Atmospheric Deposition Program, 1993, NADP/NTN Annual Data Summary, Precipitation Chemistry in the United States, 1992, Natural Resource Ecology Laboratory, Colorado State University, Fort Collins, Colo., 480 p.

Nilles, M.A., 2000, Atmospheric deposition program of the U.S. Geological Survey: U.S. Geological Survey Fact Sheet FS-112-00, 6 p.

Nilles, M.A., and Conley, B.E., 2001, Changes in chemistry of the precipitation in the United States, 1981-1998: Water, Air, and Soil Pollution, v. 130, p. 409-414.

Reuss, J.O., Vertucci, F.A., Musselman, R.C., and Sommerfeld, R.A., 1993, Biogeochemical fluxes in the Glacier Lakes catchments: General Technical Report RM-314, U.S. Department of Agriculture, Forest Service, Rocky Mountain Forest and Range Experimental Station, Fort Collins, Colo., 27 p.
Turk, J.T., and Campbell, D.H., 1987, Estimates of acidification of lakes in the Mt. Zirkel Wilderness Area, Colorado: Water Resources Research, v. 23, p. $1757-1761$.

Turk, J.T., and Campbell, D.H., 1997, Are aquatic resources of the Mount Zirkel Wilderness Area in Colorado affected by acid deposition and what will emissions reduction at the local power plants do? U.S. Geological Survey Fact Sheet FS-043-97, 4 p.

Turk, J.T., Campbell, D.H., Ingersoll, G.P., and Clow, D.W., 1992, Initial findings of synoptic snowpack sampling in the Colorado Rocky Mountains: U.S. Geological Survey Open-File Report 92-645, 6 p.

Turk, J.T., Campbell, D.H., and Spahr, N.E., 1993, Use of chemistry and stable sulfur isotopes to determine sources of trends in sulfate in Colorado: Water, Air, and Soil Pollution, v. 67, p. 414-431.

Turk, J.T., Taylor, H.E., Ingersoll, G.P., Tonnessen, K.A., Clow, D.W., Mast, M.A., Campbell, D.H., and Melack, J.M., 2001, Major-ion chemistry of the Rocky Mountain snowpack, USA: Atmospheric Environment, v. 35, p. 3957-3966.

U.S. Environmental Protection Agency, 1999, Progress report on the EPA Acid Rain Program, http://www.epa.gov/airmarkets/acidrain/ (accessed August 2001).

Western Regional Climate Center, 2001, http://www.wrcc.dri.edu (accessed August 2001).

Williams, M.W., Baron, J., Caine, N., Sommerfeld, R.A., and Sanford, R., Jr., 1996, Nitrogen saturation in the Rocky Mountains: Environmental Science and Technology, v. 30, p. 640-646.

\section{For additional information visit Web site:}

http://co.water.usgs.gov/projects/CO53100/CO53100.html 